\title{
Local development through social and territorial innovation: An exploratory case study
}

\author{
Susana Bernardino \\ J. Freitas Santos
}

ABSTRACT: This investigation aims to examine innovation in a selected successful Portuguese social venture (The Cooperative Terra Chã) and to analyse the extent to which innovative social ventures are able to contribute to local development. Specifically, the paper highlights the activities developed by the social organization in response to the needs of particular (micro) segments of society and illustrates which key factors triggered the success of the examined social initiative. A case study methodology is used to describe the distinctive characteristics and strategies pursued by the managers of the social venture and to establish the links between the opportunities for social innovation and the teritory. The data collected for the study were triangulated from desk research and from in-depth semi-structured interviews conducted with privileged actors.

The results show that social innovation is a viable strategy to revitalize the region's socio-economic tissue, through the creation of new economic activities and consequently local employment that are based on the village's traditional activities. This strategy seeks to achieve sustainable economic growth and well-being for the people of the region. However, to be successful, the strategy demands a deep knowledge of existing social problems as well as the availability of endogenous local resources and capabilities for use by social entrepreneurs. In this context, social innovation should be a participatory process, in which different entities and the beneficiaries of social programs were active players.

KEYWORDS: Social innovation, social ventures, social entrepreneurship, endogenous development, regional resources and capabilities.

ECONLIT CODES: L31, O35, R11.

How to cite this article: BERNARDINO, S. \& SANTOS, J.F. (2017): "Local development through social and territorial innovation: An exploratory case study", CIRIEC-España, Revista de Economía Pública, Social y Cooperativa, 90, 159-187.

Correspondence: Susana Bernardino, Politécnico do Porto/ISCAP/CEOS.PP, susanab @ iscap.ipp.pt; J. Freitas Santos, Politécnico do Porto/ISCAP/CEOS.PP and Universidade do Minho/NIPE, jfsantos@ iscap.ipp.pt. 


\section{RESUMEN}

\section{Desarrollo local a través de la innovación social y territorial: un estudio de caso exploratorio}

El territorio ha sido reconocido en la literatura como el lugar central para la innovación. Esto porque el espacio geográfico promueve la conexión entre el "software" de los emprendedores y el "hardware" constituido por la comunidad social, las instituciones formales e informales, así como las infraestructuras tangibles e intangibles que existen en el territorio.

Esta investigación pretende examinar la innovación en una organización social portuguesa exitosa y analizar en qué medida las organizaciones socialmente innovadoras pueden contribuir al desarrollo local. En concreto, el artículo enfatiza las actividades desarrolladas por la organización social en respuesta a las necesidades particulares de (micro) segmentos de la sociedad e ilustra cuáles son los factores que promueven el éxito de la organización social en análisis. Además, el caso pretende analizar los recursos y capacidades endógenos del territorio, así como el vínculo entre las oportunidades para la innovación social y el territorio.

Para alcanzar estos propósitos, se adopta la metodología del estudio de caso, a fin de obtener un conocimiento valioso sobre las características y estrategias distintivas perseguidas por los gestores de la organización social. Los datos colectados para el estudio se han triangulado, a través de la recogida de información secundaria por los investigadores y de la realización de entrevistas semiestructuradas en profundidad con actores privilegiados.

El caso seleccionado fue el de Cooperativa Terra Chã, una cooperativa multisectorial ubicada en una pequeña villa en la costa oeste de Portugal, que está inserta en un área protegida.

La cooperativa Tierra Chã fue fundada en 2001. A través de sus actividades, la Cooperativa pretendía responder a dos cuestiones principales: (i) ¿Lo que se debe hacer para mantener el pueblo socialmente, económicamente y culturalmente viable, una vez que la agricultura ha dejado de ser la actividad principal de estas personas? (ii) ¿Qué tipo de intervenciones pueden realizarse en un territorio cuyo principal factor de competitividad es su ubicación en un Parque Natural?

En este contexto, los principales propósitos para la creación de la Cooperativa fueron: (i) mantener el desarrollo sostenible de la región a través de la conservación de la naturaleza, la gestión de las complementariedades en el uso del territorio y la reducción de las disparidades internas; (ii) Aumentar 
el potencial endógeno a través de acciones concebidas para mejorar la calidad de vida de los residentes y asegurar la corrección de fuertes disfunciones ambientales; y (iii) generar efectos multiplicadores y sinergias para fomentar la diversificación del ecosistema socioeconómico de la región.

Para lograr estos objetivos, la Cooperativa Terra Chã desde su inicio comenzó su actividad económica, proporcionando servicios y apoyando la producción local en la aldea de "Chãos". La Cooperativa Terra Chã también buscó aumentar el atractivo económico de la aldea a través de la explotación de sus recursos endógenos y de la revitalización de sus actividades tradicionales de una manera más eficiente y moderna, al mismo tiempo que buscaba la preservación de sus tradiciones y patrimonio cultural.

Buscando aprovechar las características montañosas de la aldea, así como del conocimiento de sus habitantes, la cooperativa ha desarrollado varias actividades, que pueden agruparse en cinco categorías principales: (i) alojamiento y restauración; (ii) el turismo y la naturaleza; (iii) actividades de silvicultura y medio ambiente; (vi) apicultura; y (v) artesanía.

La Cooperativa pretendía construir y asegurar ventajas competitivas sostenibles que permitieran responder a las dos principales preocupaciones antes mencionadas, de una forma conjunta y sinérgica. Las actividades realizadas buscaban desde el principio ser económicamente viables, a través del desarrollo de fuentes de generación de ingresos directamente relacionadas con las actividades desarrolladas. La cooperativa reinventó actividades económicas teniendo en su base las tradiciones de la aldea, sus recursos naturales, así como sus características geológicas y geomorfológicas. La innovación social aseguró la viabilidad de las técnicas tradicionales, añadió valor a los productos locales y permitió atraer turistas a lo pueblo. Todas las actividades fueron soportadas por los recursos locales e interconectadas con el conocimiento local de modo a crear sinergias. La innovación social se encuentra en el corazón de esta estrategia diseñada para estimular el desarrollo económico, social y medioambiental de la comunidad. La estrategia también implicó que la Cooperativa haya reequilibrado su fauna y flora local, permitiendo al mismo tiempo que las actividades tradicionales fueran desarrolladas con estándares de calidad más elevados.

Las actividades desarrolladas han producido resultados considerables, incluso en un área rural prácticamente desierta que fracasó en atraer el interés de las empresas tradicionales y ha sufrido fuertemente con la desintegración del sector económico portugués. En primer lugar, el proyecto alcanzó importantes resultados relacionados con la creación de empleo, ya sea directamente o indirectamente, en particular en relación con las mujeres que nunca habían participado en el mercado de trabajo formal. La estrategia también contribuyó a prevenir la despoblación rural y mantener estable el número de habitantes. Las actividades realizadas también permitieron generar un impacto turístico significativo y contribuir al desarrollo económico, especialmente enfocado en los recursos endógenos. 
La investigación revela que el factor crítico es encontrar una solución que permita preservar el conocimiento y las tradiciones de la población, así como aprovechar sus recursos locales.

Las actividades más antiguas (y ancestrales) se han rediseñado para permitir atraer nuevas generaciones de personas y detener la migración de la población local a otras localizaciones centrales y litorales con mejores condiciones de empleo. La actividad de la cooperativa ha contribuido a la cohesión social, procurando conectar a las personas más jóvenes a actividades económicas desarrolladas en lo propio pueblo, así como la creación de empleo y la creación de fuentes de ingresos aceptables.

El proceso de desarrollo económico local implicó aún un proceso participativo, incluyendo a actores privados y públicos. Además, los beneficiarios de los programas sociales también fueron actores activos en el modelo de respuesta social, teniendo los programas de capacitación un papel importante. La evidencia obtenida soporta las teorías de los sistemas de innovación regional, ya que los aprendizajes colectivos basados en las relaciones de cooperación activa son cruciales para el desarrollo de nuevos modelos de respuesta que permitan abordar los problemas sociales incorporados en un determinado territorio. Al mismo tiempo, la interacción de un conjunto de entidades locales llevó a la generación de un conocimiento más preciso de las especificidades del territorio y el modo en que éstos moldean las oportunidades y limitaciones que podrían ser explotadas para la creación de valor social.

La principal limitación de la investigación reside en que se basa en un estudio de caso único, aunque este enfoque permite obtener un conocimiento más profundo del tema en cuestión. La investigación permitió avanzar con el conocimiento sobre innovación social, territorios y desarrollo local, realizando un estudio empírico donde se intenta probar el vínculo entre estos conceptos. El caso elucida las principales características de las actividades perseguidas por la Cooperativa Terra Chã, que podrán ser usadas como benchmarking para otras iniciativas sociales insertadas en contextos sociales y territorios semejantes.

PALABRAS CLAVE: Innovación social, emprendimiento social, desarrollo endógeno, recursos y capacidades regionales. 


\section{1.- Introduction}

Innovation is one of the main causes of economic growth, and the social entrepreneur is the main driver of social innovation in modern economies. Today's challenges have taken on an increasingly social dimension, and innovative responses to problems and needs should be imagined and initiated on the ground by the social entrepreneur (Hoogendoorn \& Hartog, 2011; Essers, Dey, Tedmanson \& Verduyn, 2017).

One of the most prominent societal challenges is increasing unemployment, which is often linked to crime and social exclusion. Unemployment has long-lasting consequences not only for those losing their jobs but also for their children, who consequently have fewer opportunities in society (European Communities, 2011; Cantillon, Chzhen, Handa \& Nolan, 2017). The emergence of social actors' initiatives to satisfy specific social needs and offer solutions to different problems derives mostly from the employment crisis and the reshaping of State interventions (Bouchard, 2011). In this context, social innovation plays a central role in solving new societal problems.

A growing number of institutions and local entities have adopted social innovation as an instrument of political action with respect to employment, intergenerational population stability, economic development and sustainability, and other social issues. In the policy of the European Union, social innovation is mentioned as a strategic element of a more intelligent, sustainable and inclusive Europe and as a response to the social challenges of the internal market (European Communities, 2011).

These new strategies are pursued at the local level not only by domestic governments and local authorities (largely supported by European funds), but also by not-for-profit and private organizations through initiatives of corporate social responsibility. The approach developed focuses largely on local problems, where proximity is a critical factor to identify and evaluate these problems and to improve efficiency in the actions taken. These actions relate to the dynamism of the social system, the vitality of the formal and informal local social ecosystem and the emergence of new forms of intervention adopted by local organizations.

Innovative responses to problems and needs have been published in the form of research reports of various international organizations (e.g., European Commission) and foundations (e.g., Young Foundation) (Choi \& Majumdar, 2015). To the best of our knowledge, however, academic research on the role of social innovation in local development is scant. Therefore, the analyses of paradigmatic case studies by academics at the operational level could enhance our knowledge base to enable us to better understand the mechanisms of social innovation in underdeveloped regions. Based on the social 
and territorial innovation model's framework, this investigation uses in-depth case study analysis to examine how social innovation that arose from the territory has contributed to local development. In this context, a number of benefits can be drawn from this research. First, the present study adds to academic empirical knowledge by assessing the extent to which members of the community manage to launch new ventures that take advantage of the resources and capabilities of the territory to generate sustainable businesses, create new jobs and maintain traditional know-how. Second, the study helps to identify the specific role of social innovation originating from a small and underdeveloped region, with the potential for local economic development from below. Specifically, the research focuses on the characteristics of the territory (culture, natural and social heritage, etc.) and the local community where the inhabitants jointly decide on the products to be offered and the tourist attractions to be implemented in order to achieve a competitive and sustainable advantage in the market.

Third, from a regional perspective, the study provides both social entrepreneurs and public policy makers with valuable information on how to deal with problems and issues emerging from the entrepreneurs' resource allocation decisions. By providing a detailed description of a successful social venture of how an integrated strategy for managing the resources and capabilities of a territory, the case could inspire other social entrepreneurs to cope with similar social issues that are not being adequately addressed by other stakeholders. The originality of the study consists of analysing the contribution of territorial innovation models and social innovation to local development in a holistic way, bringing new insights to regional development literature.

The paper begins by discussing the notion of social innovation and explaining how it can be used as an analytical framework to understand the launch of new social ventures in underdeveloped regions. The next section reviews the literature on territorial innovation models and describes how these different models contribute to social innovation. The employed case study methodology is then explained. Subsequently, the Cooperative Terra Chã, an agricultural multi-sector cooperative located on the central west coast of Portugal, is examined, and the research findings are presented and discussed, with the emphasis placed on managerial implications. Finally, the conclusion section develops recommendations for social entrepreneurs and policy makers. 


\section{2.- Social Innovation}

The upsurge of social innovation among researchers has not been accompanied by a consensus in the literature regarding the scope and dimensionality of the concept. From an institutional point of view, social innovation is about "new ideas (products, services and models) that simultaneously meet social needs (more effectively than alternatives) and create new social relationships or collaborations" (European Communities, 2011: 9). According to OECD (2010), social innovation seeks new answers to social problems by: i) identifying and delivering new services that improve the quality of life of individuals and communities; and ii) identifying and implementing new labor market integration processes, new competencies, new jobs, and new forms of participation, as diverse elements that each contribute to improving the position of individuals in the workforce.

From an academic perspective, social innovation is a "creative process, mostly collective, driven by the purpose of social utility that tries to establish a link between knowledge and competences of various actors in order to obtain a certain level of well-being starting from a community that plays the role of disseminator" (Guida \& Maiolini, 2014: 15). Clarence (2014: 47) defines social innovation as looking for new ideas and ways of working to meet unmet needs involving concepts, products, and organizations to address social problems and challenges. Social innovation usually happens by trial and error, learning-by-doing, and exchanging ideas within groups where the exchange of opinions assures new ways of doing things.

The key distinction between social innovation and other types of innovation (i.e., commercial and technological) is that social innovation is oriented to the social and public good rather than to the market (Edwards-Schachter, Matti \& Alcântara, 2012). Another difference occurs both in its outcomes and in its relationships, as well as in the new forms of cooperation and collaboration that it brings (Murray, Caulier-Grice \& Mulgan, 2010). As Phills, Deiglmeier and Miller (2008) pointed out, social innovation refers to any novel and useful solution to a social need or problem that is better (i.e., more effective, efficient, sustainable, or just) than existing approaches and for which the value created (benefit) accrues primarily to society as a whole rather than to private individuals. According to Phills et al. (2008), the microfinance and fair trade examples could illustrate the prior definition. Novy and Leubolt (2005) state that social innovation mainly stems from the satisfaction of basic human needs, an increased level of political participation from deprived groups, and the increased socio-political capacity and access to resources needed to enhance rights to enable the satisfaction of human needs and participation.

One important contribution for the study of social innovation derives from the review of 49 studies conducted by members of the Centre de Recherche sur les Innovations Sociales (CRISES) (Tardif \& Harrison, 2005). The analysis found five common dimensions: transformations, innovative character, 
characteristics of innovation, actors involved, and process of developing the innovation (Klein, Fontan, Harrisson \& Levesque, 2012; Maurer \& Silva, 2014). The transformation dimension refers to the context in which the innovation is developed and includes three aspects: i) macro and micro contexts with the identification of crisis, ruptures, discontinuities and facts that force people to rethink their actions and develop new solutions for times of social and economic crises; ii) territorial contexts (local, regional and national) that are adapted or developed to promote change in production, consumption and work relations; and iii) social context with the identification of problematic contexts in social structures (e.g., marginalization and socioeconomic exclusion). The second dimension refers to the innovative character that indicates the central role of social action as a source of innovation in a given territory, since actors are induced to search for innovative solutions to problems they identify in their context.

The third dimension comprises the types of innovation (technical, socio-technical, social, organizational and institutional), their scale (local or localized innovations) and their purposes (individual, collective, general, or common good). The fourth dimension includes the actors (individuals, organizations, institutions and intermediaries) involved in the social innovation process. The individuals comprise civil society, cooperative movements, associations and unions. The organizations can be companies, social economy organizations, collective organizations or beneficiaries. Institutions are understood to be the state as well as established norms, values and identity. Lastly, the intermediaries emerge from the interactions among the different actors, committees, social networks, alliances and innovation networks. The fifth dimension relates to processes and involves three elements: i) methods of coordination, which indicate the way in which the actors interact and structure the process of social innovation, as well as how they share and disseminate information, knowledge and practices as they develop social innovations; ii) modes of implementation, which encompass cooperation, partnerships, integration, negotiation, and diffusion, among others; and iii) constraints, including complexity, resistance, tensions and uncertainties among the actors when faced with something new.

Social innovation is accelerated by the pressures caused by societal changes (Moulaert, MacCallum \& Hiller, 2013). In the words of the same authors (2013: 14), social innovations can be understood as "reformist "solutions' for the scarcity of the resources in the welfare state" and as a "reformist approach to solve social problems". Thus, social innovation increases the satisfaction of social needs such as exclusion, deprivation, alienation, and lack of wellbeing and allows for the attainment of significantly higher wellbeing and human progress, as well as development. In this sense, social innovation is seen as a kind of innovation, characterized by its intentionality, which evolves by reshaping the society and aspiring to bring more effective and efficient solutions to social problems (Franz, Hochgerner \& Howaldt, 2012).

Klein (2013: 9) argues that social innovation is seen as a "tool box that could provide rapid solutions to pressing problems" of the most vulnerable segments of society. It is also considered to be a way to foster the social cohesion of territories. Social innovation is further seen as being able to positively contribute to social, spatial and ecological development, at the same time that promotes the principle of social justice (Dyck \& Broeck, 2013). As stated by OECD (2014: 148), "innovation can make 
a substantial contribution to dealing with social challenges such as poverty, ageing, social exclusion and health". Also, as stressed by Neumeier (2017, p.34) "social innovation is often seen as a means for realising development and growth by replacing governmental involvement by building on citizens and enterprises as self-reliant development actors who take change and development into their own hands". Therefore, innovation is considered to be an important driver of growth, while it plays a key role in shaping inequalities and in helping to support well-being (OECD, 2014). As stressed by Cosseta and Palumbo (2014), innovation is considered the unique antidote to the crisis and to the inequality that exists in the society.

Opportunities for social innovation are shaped by historical circumstances (Mulgan, 2012). Social innovation is highly contextual and path dependent, since it is strongly embedded in the social-cultural and social-political context (Moulaert et al., 2013). Also, it is socio-spatially embedded and time-bound, as it is closely interlinked with the stakeholder ecosystem and embedded in local systems and territorial networks (Cosseta \& Plumbo, 2014; Moulaert et al., 2013). Therefore, as stressed by Dyck and Broeck (2013), innovation should be conceived under its spatial-historical context, taking into account the material territoriality, as well as the social dimension of territories. Furthermore, social innovation can emerge from the actions taken by communities in order to alleviate social, political and/or material issues (Moulaert et al., 2013). According to Neumeier (2017, p. 35) to be successful, social innovation should address four main criteria: "(i) it is innovative with regard to the user, context or application; (ii) it meets needs more effectively than pre-existing alternatives; (iii) it provides long-term solutions; and (iv) it is adopted beyond the initial group/network that developed it".

\section{3.- Territorial Innovation Models}

The external environment matters for success in innovative activity as least as much as internal factors (Porter, 2001). An attractive environment for innovation, such as university-industry linkages or a large pool of highly qualified workers, depends markedly upon the characteristics of a territory. A wide variety of territorial innovation models have emphasized the characteristics of the territory as a place for innovation. The basic idea is that the geographical space links the "software" of the entrepreneur to the "hardware" made up of the social community, the formal and informal institutions, and the tangible and intangible infrastructures that exist in its territory (Leoncini \& Montresor, 2008).

The theory of the innovative milieu argues that firms have a support space constituted around three types of relations: i) qualified or privileged relations with regard to the organization of productive factors; ii) strategic relations between the firm and its partners, suppliers and clients; and iii) strategic relations with agents belonging to the territorial environment (Aydalot, 1986; Moulaert \& Sekia, 2003; 
Camagni \& Maillat, 2006; Santos \& Simões, 2014). The GREMI (Groupe de Recherche sur les Milieux Innovateurs) studies have empirically demonstrated the existence of a dynamic and embedded productive system in different regions and countries (Camagni, 1991; Maillat \& Perrin, 1992).

Building on a new interpretation of Marshall's work, Becattini (1990; 2015) develops the Marshallian industrial district concept as a socio-territorial entity characterized by the active presence of both a community of people and a population of firms in one naturally and historically bounded area (Becattini, 1990; Sforzi, 2015). The concept postulates that economic change emerges concretely within and between places, and so economic change is a socio-economic place-based process (Santos \& Simões, 2014; Sforzi \& Boix, 2015). The concept of industrial district has been supported empirically, indicating the importance of the place within various types of localities, including countries, regions, big cities and rural areas (Pyke, Becattini \& Sengenberger, 1990; Sengenberger, Loveman \& Piore, 1990; Pyke \& Sengenberger, 1992; Benko \& Lipietz, 1992; Bellandi \& Propis, 2015).

The local innovation system is a generalization of the industrial district view of local economic development (Moulaert \& Sekia, 2003). It is characterized by the territorial proximity of productive units (firms, plants, service suppliers, R\&D centers, training institutions) interlinked in different forms (formal and informal, material and immaterial, market and non-market). Industrialization is perceived as a process occurring in urban or rural areas with an explicit artisan tradition (Courlet, 2008). The results of the empirical evidence emphasize the factors on which local productive systems base their reproduction and renovation, such as external economies, non-transferable knowledge, specific forms of regulation, and strong local identity (Courlet \& Pecquer, 1992; Moulaert \& Sekia, 2003; European Union, 2014; Ferreti \& Parmentola, 2015).

Using the industrial district perspective, the new industrial spaces paradigm goes beyond the agglomerated production systems by encompassing: i) the coordination of inter-firm transactions and the dynamics of entrepreneurial activity; ii) the organization of local labor markets and social reproduction of workers; and iii) the dynamics of community formation and social reproduction (Moulaert \& Sekia, 2003; Gathfield \& Yang, 2006). The research of Scott $(1988,2014)$ leads to the identification of new industrial spaces in North America, Western Europe and Norway (Isaksen, 1994).

According to Porter (1988), a cluster is a geographic concentration of interconnected companies, specialized suppliers, service providers, firms in related industries, and associated institutions (for example, universities, standards agencies, and trade associations) in particular fields that compete but also cooperate. Following the new industrial spaces literature, the cluster of innovation approach reinforces the role of local institutions and culture as well as industrial structure and corporate organization for economic performance (Moulaert \& Sekia, 2003). A large number of studies have identified clusters all over the world in different industries (Enright \& Roberts, 2001; Feser, 2002; European Communities, 2008, Potter \& Miranda, 2009; Chatterji, Glaeser \& Kerr, 2013). 
The concept of regional innovation systems has no commonly accepted definition, but it is usually understood as a set of interacting private and public interests, formal institutions and other organizations that function according to organizational and institutional arrangements and relationships conducive to the generation, use and dissemination of knowledge (Doloreux, 2003). The theory of regional innovation systems stresses the role of collective learning based on deep cooperative relationships between members of the system (Moulaert \& Sekia, 2003). This learning process, combined with firm-specific competences, can lead to regional competitive advantages if it is based on localized capabilities such as specialized resources, skills, institutions and shared social and cultural values (Braczyk, Cooke \& Heidenreich, 1998; Doloreux, 2002; Santos \& Simões, 2014). Cooke and Morgan (1994) identify a regional innovation system in Baden-Württemberg; Diez (2002) in the metropolitan areas of Barcelona, Stockholm, and Vienna; and Doloreux (2003) in Beauce in Québec (Canada).

Drawing on the work of evolutionary political economy, learning regions provide the crucial inputs required for knowledge-intensive economic organization to flourish: a manufacturing infrastructure of interconnected vendors and suppliers; a human infrastructure that can produce knowledge workers, that facilitates the development of a team orientation, and that is organized around life-long learning; a physical and communication infrastructure that facilitates and supports constant sharing of information, electronic exchange of data and information, just-in-time delivery of goods and services, and integration into the global economy; and capital allocation and industrial governance systems attuned to the needs of knowledge-intensive organizations (Florida, 1995; Morgan, 1997; Santos \& Simões, 2014). Some empirical evidence of learning regions can be found in the technology districts of France, Italy and the United States (Storper, 2007).

In brief, the aforementioned theoretical approaches consider different types of territory. For the innovative milieu and the local production systems approaches, the territory is a support space where agents modify their behavior according to changes in the environment. In contrast, the industrial district paradigm takes a limited space view of the environment as a source of constraints and opportunities to which agents must react. For the regional innovation system and learning region theories, the specific internal relations with the environmental constraints are emphasized. Finally, the new industrial spaces model underlines the dynamics of community formation and social reproduction. In this sense, the dynamic capabilities of the territory make entrepreneurs capable of interacting with their host environments and of running a process that depends not only on their learning capacity but also on their hosting environment (especially the territorial one) and their constituting resources (especially the human ones; Leoncini \& Montresor, 2008). 


\section{4.- Methodology}

The objective of the present study is to examine innovation in a selected successful Portuguese social venture. The aim is to produce knowledge that could be transferred (by emulation or adaptation) to other ventures, social contexts and territories. To achieve this goal, we adopted a case study methodology to obtain valuable insights about the different characteristics and strategies pursued by the managers of the social venture. Specifically, we intend to highlight the activities developed by the social organization in response to the needs of particular (micro) segments of society. The selected case is expected to illustrate which key factors triggered the success of the examined social initiative.

Case study research in some areas, such as social innovation, is a very useful method of gaining insight about well-managed initiatives known for their abilities to innovate and execute where there is little theory available to serve as a guide (Eisenhardt, 1989; Ghauri, Gronhaugh \& Kristianslund, 1995; Yin, 2013). Further, innovation is a social-fact-driven process (Cosseta \& Palumbo, 2014) and therefore should be considered to be embedded in a given context and society.

A single-case design is considered appropriate since it enables the "researcher to get a deeper understanding of the subject" and is more suitable to explore theoretical relationships (Gustafsson, 2017, p.4). However, single-case designs are often regarded as somewhat suspect, as heavy sample bias implies problems of external validity (Bryman, 2001). Nonetheless, a basic lack of knowledge about the phenomenon often warrants explorative research based on a single case (Jonsson \& Foss, 2011). Also, the use of qualitative methods offers the opportunity to help advance the field and assist in providing its own theoretical grounding (Doz, 2011). As Dyer and Wilkins (1991) noted, if executed well, case studies can be extremely powerful when their authors are able to describe a general phenomenon so well that others have little difficulty seeing the same phenomenon in their own experience and research. Dyer and Wilkins (1991) also argue that the ultimate goal of case study research is to provide a rich description of the social scene, to describe the context in which events occur, and to reveal the deep structure of social behaviour. The qualitative methodology also gives the researcher great freedom, both in case selection and in the choice of information sources and analytical techniques. Such freedom makes it imperative for the researcher to clarify, from the beginning of the investigation, the main goals and structure of the research in order to avoid including unsuitable information.

The structure for the in-depth case study analysis is as follows. First, we provide information about the social venture; then, we examine the dynamic capabilities of the specific territory; finally, we focus on the main features of the social innovation process and the opportunities generated by the territory. This approach helps us to organize the data collection and interpretation and metaphorically serves as a dialogue partner for the data (Jonsson \& Foss, 2011). We thus contribute to the growing need 
for qualitative research within the social innovation field, especially in the context of the role of the dynamic capabilities of the territory in the generation of opportunities for social innovation.

The data for this study were collected from two different sources: desk research and in-depth, semistructured interviews. These sources were triangulated to improve the accuracy of judgments and strengthen the validity of the results (Ghauri et al., 1995).

Desk research was conducted based on secondary data previously obtained by the authors about Cooperative Terra Chã, as well as information displayed in the organization's' site and covered by the statutes of the selected institution. Then, to clarify some aspects of the analysis and enhance the content of the case study, two interviews were conducted with the members responsible for the management of the Cooperative.

The reasons for focusing on this case were as follows: first, it represents a successful social venture developed in an underdeveloped rural area with problems ranging from employment to lack of industries; second, it may serve to explore ideas about the role of small-scale social initiatives in the regional development literature. Thus, this case may elucidate the main features of the activities undertaken by the Cooperative that can be used as benchmarks for other social initiatives located in lessdeveloped regions.

The two interviews started with open questions about the Cooperative and other aspects related to past, present and future projects. As the interviews progressed, the questions gradually became more structured, delving into more precise questions about how the activities were processed. The first interview took place in July 2013, and the second occurred in March 2016. Both interviews lasted between 30 and 45 minutes. The data obtained in the interviews were triangulated with the data collected by desk research, which allowed us to control for memory bias.

To analyse the data, we followed the aforementioned structure for the case study. In this approach, the empirical patterns of the case were detached in order to address the main features related to the territory dynamic capabilities, the generation of opportunities for social innovation and its appropriation by the social entrepreneur. 


\section{5.- The Mechanisms of Social Innovation at the Territorial Level: The Case of Cooperative Terra Chã}

This case attempts to analyze the endogenous resources of the territory and simultaneously establish the links between the opportunities for social innovation and the territory. This is done by using the primary data collected in the interviews with privileged observers and examining secondary data from several sources.

\section{Cooperative Terra Chã}

This multi-sector cooperative was founded in 2001 and started its economic activity by providing services and supporting local production in the "Chãos" village. Its main aims are to create conditions for: i) maintaining the sustainable development of the region through the conservation of nature, the management of complementarities in the use of the territory and the reduction of internal disparities; ii) enhancing its endogenous potential through meaningful actions conceived to improve the quality of life of the residents and to ensure the correction of severe environmental dysfunctions; and iii) generating multiplier effects and synergies to encourage the diversification of the region's socio-economic ecosystem.

\section{Endogenous resources of Chãos}

Chãos is a small village with about 160 inhabitants, surrounded by mountains and located in the protected area of the National Park of "Serras de Aire e Candeeiros", in the municipality of Rio Maior (on the central west coast of Portugal). Table 1 provides an inventory of the main endogenous resources that can be found in the village. A simple classification based on tangibility (i.e., tangible vs. intangible) is useful to identify and appraise the territory's resources. 


\section{Table 1. Endogenous Resources of Chãos}

\begin{tabular}{|l|l|}
\hline Type of endogenous resource & Characteristics \\
\hline Tangible & $\begin{array}{l}\text { Topography (hilly terrain, covered by scarps and outcrops). } \\
\text { Landscape. Forests. Calcareous soil. Largest underground reser- } \\
\text { voirs of freshwater in the country. Caves (Grutas de Alcobertas, } \\
\text { from the upper palaeolithic period) have been classified as a } \\
\text { national monument and contribute to preserve the local fauna and } \\
\text { high diversity of species. }\end{array}$ \\
\hline Intangible & $\begin{array}{l}\text { Workforce has a deep knowledge of traditional farming techniques } \\
\text { due to intergenerational transmission of knowledge and experience. } \\
\text { Most of the young villagers have graduated. Common background } \\
\text { (e.g., cultural heritage, psychological). Geographical proximity and } \\
\text { cooperation between individuals and local institutions. } \\
\text { Entrepreneurial dynamism with knowledge, individuals capable and } \\
\text { confident enough to establish new areas of activity. Availability of } \\
\text { trained and adaptable workforce (innovative atmosphere, speed of } \\
\text { reaction, cooperative attitudes). Pervasive reliance on trust and } \\
\text { cooperation as guiding principle in business relationships. Local } \\
\text { government provides a legal and regulatory framework appropriate } \\
\text { to the specific production and services. People's craft identity links } \\
\text { individuals to an informal craft educational system. }\end{array}$ \\
\hline
\end{tabular}

SOURCE: Authors' own elaboration.

\section{Social innovation activities}

The cooperative has developed several activities, which can be grouped into five major sections: (i) accommodation and food services; (ii) tourism and nature; (iii) silvo-pastoral activities and environment; (iv) beekeeping; and (v) handicrafts.

The Cooperative intended to build an enduring and sustainable advantage that aims to respond to the two main concerns mentioned above in a simultaneous and reinforcing manner. This implies that the Cooperative needs to rebalance the local flora and fauna while, at the same time, making it possible to develop traditional activities with higher quality standards.

One of the species that has suffered greatly from environmental changes is the red-beaked magpie. This endangered bird plays a crucial role in biodiversity. The presence of the red-beaked magpie favors the reappearance of some kinds of flowers and plants that were originally embedded in the territory, by improving the soils fertilization. The increased biodiversity led to the appearance of plants that are important to honey production, by means of pollination and the reappearance of some kind of 
bees. Likewise, the renewed flora enables the production of better quality cheese, since goats have also a more nutritional feed. It should be highlighted that the village of Chãos has important geographic conditions to accommodate this endangered species, namely the caves and ravines in which the birds nest.

Apiculture is an activity with a strong tradition in the Village of Chãos, as well as in all the surrounding mountainous area (Serra dos Candeeiros). In fact, in the past, the majority of the families had beehives, used to produce honey for their own consumption or even to be sold to the market. Further, the honey produced in the area was highly valued, especially due to the impressive diversity offered by the calcareous nature of the mountain, which is important for the beekeeping activity. Finally, the weather conditions (e.g., air temperature, humidity, precipitation, and wind strength) have an influence on the "productivity" of honey bees.

However, in recent years, the region has been affected by some diseases that harm the bee-hives and the honey production. Further, the insulation caused by the mountainous characteristics of the area makes it difficult to introduce new equipment and working methods into the region.

In addition to the economic value of beekeeping, this activity is particularly important for the preservation of protected species due to the biological services provided by bees, such as pollination, which favors the preservation of local spontaneous flora. Thereby, the Cooperative recognized the importance of (re)valorizing the beekeeping activity, through a strategy designed to link training and the creation of infrastructures (facilities and equipment) that enabled the production of high-quality hive products.

With this purpose in mind, the Cooperative first decided to implement a network of beekeepers and, then, to construct a collective honey center.

The main aims were to develop a set of actions that could improve the production and marketing of apiculture products; to provide technical assistance to beekeepers through the monitoring and qualification of their production; and to promote consumers' awareness about honey. In the community center, its associates (the villagers) may extract honey in the facilities of the center that provide storage conditions and packaging in accordance with all the current legal standards. Furthermore, the project promotes the capacity for innovation as well as the marketing and commercialization of honey and other apiculture products. Through this association, beekeepers do not need to invest in the creation of various infrastructures, and their activities become (more) economically sustainable.

Furthermore, the Cooperative also intend to build an interpretive space (which includes an experimental apiary), where bees and their role in terms of biodiversity are presented to the public. The creation of this space is intended to develop the knowledge and qualification of beekeepers, to provide technical support, and to raise awareness about beekeeping as a possible economic activity, especially among the younger population. In fact, it is expected that this project will generate new motiva- 
tions for beekeeping, making it a more attractive activity for young people. The collective center will be financed by revenue from its members' contributions, by the money gained from the sale of honey, by the admission of new members and by tourist activities related to the interpretation center (Fagundes, 2014).

Cooperative Terra Chã also has sought to enhance the economic attractiveness of the village by means of the regeneration of grazing activities as a potential economic activity. Based on a partnership established with private entities, the cooperative decided to create a collective herd composed of autochthone goats, which are appropriate to the characteristics of the local territory. Furthermore, the goats also play an important role in vegetation control and forest fire prevention.

In addition, the Cooperative has sought to explore nature tourism. For that purpose, it established activities such as nature tours, observation of plant species and hiking routes in architectonic and speleological heritage, that promote tourism. An example of this was the creation of the "Pastors' Route", a recreational activity involving walking on selected routes. The aim of this activity is (i) to attract tourists to the region, (ii) to show the natural beauty of the village; and (iii) to raise awareness of environmental issues and pastoral activities.

The nature tours also enable its participants to acknowledge cultural issues related to pastoralism, such as the existing water supply points, the buildings used by shepherds as shelter places, or the games played in the pastors' spare time. During each walk, individuals are accompanied by two specialized monitors, who explain the route and give support to individuals if necessary. The Cooperative had designed different walking tours, characterized by several lengths and difficulty levels (ranging from $3 \mathrm{kms}$ to $16 \mathrm{kms}$ ), as well as involving particular villages' points of interest.

By means of the participation of the people who walk the route, the Cooperative seeks to promote, in an integrated manner, other local activities. For instance, each individual is given a bag (produced in the weaving center of the Cooperative) containing a traditional lunch of Chãos, composed of local products such as goat cheese, olives, traditional homemade sausage or corn bread, among others. The participants on the walk can either look for accommodations offered by the Cooperative or for other gastronomy available at the local restaurant.

Taking advantage of the village's mountainous characteristics, the Cooperative decided to develop recreational activities, such as mountain biking and radical sports like climbing and rappel. The aim of doing so was to provide to the participants contact with nature and with local culture. At the same time, these activities enable the creation of new income sources (such as the participation price or the bicycle rental), as well as the diversification of the portfolio of activities held by the cooperative (making the offering as a whole more attractive). Traditional games are also offered in order to provide recreational programs based on the village's cultural heritage. Given the variety of leisure activities provided, the Cooperative had decided to launch a holiday camp, in which individuals can customize their own activities. 
The accommodation activities also play an important role. Terra Chã currently has two accommodation centers, able to house around 36 individuals. The buildings benefit from the natural location, since they have balconies with panoramic sights of the mountains. Their conception also makes use of other activities provided by the cooperative, since the curtains and carpets were produced by the weavers of the weaving shop. The accommodation is conceived in order to support (and to benefit from) individuals who visit the Chãos village and stay there for a given period of time. Specifically, it can be used by individuals who intend to enjoy the environmental and leisure activities offered by the cooperative as well as the available training programs (e.g., to speleology and archaeology).

In the proximity of the accommodation centers there is a restaurant, offering traditional cuisine made with local products, such as kid or goat's cheese.

The Cooperative Terra Chã's strategy also comprises activities related to handicrafts. The aim was to preserve and develop craftwork in the region by introducing innovation in the field and allowing the creation of handmade products that meet the needs of the domestic and foreign consumers. The underlying purpose was to favor the creation of employment (and to support local populations to remain in the village) at the same time that local cultural traditions are preserved. In addition, a shop was created by the Cooperative in order to sell the local products.

The activities developed, since its inception, sought to be economically viable, through the development of sources of revenue generation directly related to the activities performed. Notwithstanding, local population since the early years actively pursued the development of several partnerships with public and business sector, under the scope of their corporate social responsibility programs, to ensure access to critical resources, specifically for the start-up phase. The several activities that were developed by the Cooperative are kept active since they were launched, increasing the offer made available by the association The Cooperative Terra Chã.

The activities developed have produced considerable outcomes. Firstly, the project has attained important results related to job creation, since about 7 individuals (in a village of 150 inhabitants) were employed directly by the Cooperative. The Cooperative has had an important role in increasing employment for female workers who had previously never participated in the formal labor market. Through flexible work practices, these women could combine their jobs in the cooperative with domestic and farming activities. Further, around 50 individuals benefit from the activity developed by Terra Chã. Thus, the main beneficiaries of the Cooperative are the population of the village and, either directly or indirectly, the populations of the nearby villages. Through the strategy pursued, the Cooperative was able to prevent rural depopulation since the number of its inhabitants has remained stable.

The activities developed have produced a significant touristic impact. The small village has received around 7,000 tourists every year, which has a very important economic impact on the region. 


\section{6.- Discussion}

Local economic development focuses on endogenous resources. It provides a means of identifying new opportunities by creating viable economic activities in a given location that could generate jobs and income for the local community. The distinctive feature of local economic development is that it involves participatory processes, in which both public and private actors are invited to take part. The effects of this social dialogue are measured not only in terms of new economic partnerships but also in terms of social cohesion and institutional transparency. The project of Cooperative Terra Chã is a benchmark for local economic development. The cooperative's aims are to contribute to social cohesion by attaching young people to economic activities developed in the village and to create jobs and decent sources of income that could deter the village inhabitants' emigration to the coastal cities of the country.

This case study describes how a significant number of inhabitants of a mountain village located in a national park founded a cooperative involving the local parish, public authorities and other supporting actors. The strategy pursued by the Cooperative is based on the promotion of economic activities that enable local development dynamics related to traditional products and tourism. The economic activity developed by the Cooperative is related to the production of honey, grazing, handcrafting, accommodation, food services and leisure activities based on nature, bringing together different experiences, knowledge, skills and natural resources. The Cooperative re-invented economic activities on the basis of the village traditions, natural endowments and the village's geological and geomorphological characteristics. The social innovation processes ensured the feasibility of traditional techniques, added value to local products and attracted tourists to the village. All the activities are supported by local endowments and intertwine with traditional know-how in order to generate synergy. Social innovation is at the heart of this integrated approach conceived to stimulate the community's economic, social and environmental sustainable development.

The Terra Chã Cooperative case reveals how employment can be promoted and created in almost deserted rural areas that have failed to attract the interest of traditional firms and have greatly suffered from the disintegration of the Portuguese economic sector. Our investigation reveals that the critical factor is to find a solution that will preserve the know-how of its population and take advantage of its local resources. Older (and ancestral) activities have to be redesigned in order to attract new generations and deter local people's migration to other central or coastal locations with better employment conditions. The Terra Chã Cooperative was also able to take advantage of the opportunity left by the consumer's profile change that currently highly value this type of products. 
The development of activities by villagers of Chãos would not have been possible without the support and training provided by the Cooperative. The beneficiaries of social programs are active players in the social response model. The social and economic value that is produced by the cooperative is, to a large extent, a result of the effort and value of their work on grazing activities, commercialization of honey products and tourism, among others. Capacity building and empowerment of members of the Cooperative is quite evident in the support given by the Cooperative to its members for carrying out agricultural or beekeeping activities and training. The technical knowledge and know-how promoted through these training programs are offered on the basis of local development initiatives, the preservation of local traditions and the protection of the environment. The evidence gathered supports the theories of regional innovation systems, since collective learning based on active cooperative relationships is crucial to the development of new response models to cope with social problems embedded in a given territory. Further, the interaction of a set of local entities led to the generation of a more precise knowledge of the specificities of the territory and the way they shape the constraints and opportunities that could be seized for social value creation. Table 2 attempts to link the territorial innovation models with the drivers of social innovation that have been critical in the development of the cooperative Terra Chã business model. 


\section{Table 2. Territorial innovation models and social innovation in the cooperative Terra Chã}

\begin{tabular}{|c|c|}
\hline $\begin{array}{l}\text { Territorial innovation } \\
\text { models }\end{array}$ & Drivers of social innovation \\
\hline Innovative milieu & $\begin{array}{l}\text { The environmental and socio-demographic changes that the village of Chãos has } \\
\text { faced fostered entrepreneurial behavior in its inhabitants. } \\
\text { The social capital embedded in the territory is crucial for the design and implementa- } \\
\text { tion of the strategy for local development. The process of social innovation at the terri- } \\
\text { torial level (village) is based on trust and reciprocity between residents who share a } \\
\text { common vision (the desire to revitalize the Chão's economy). } \\
\text { The cooperation established with other organizations (in accordance with its corporate } \\
\text { social responsibility programs) and with local entities (Municipal Council) is critical. }\end{array}$ \\
\hline Industrial district & $\begin{array}{l}\text { The activities that had a high relevance in the past (and that characterized Chãos' } \\
\text { socio-economic environment) were redesigned through social innovation processes. }\end{array}$ \\
\hline $\begin{array}{l}\text { Local innovation } \\
\text { system }\end{array}$ & $\begin{array}{l}\text { The past traditional economic entities are very close to each other. } \\
\text { The proximity between the Chãos' inhabitants can be reinforced by the small size of } \\
\text { the village and by its territory's characteristics (rural, desertified and mountainous } \\
\text { area). } \\
\text { The interaction between individuals is mainly established in an informal way and fos- } \\
\text { tered by the strong local identity. Existing relationships are also critical for the innova- } \\
\text { tion process and for the capacity to generate ideas for local development. }\end{array}$ \\
\hline $\begin{array}{l}\text { New industrial } \\
\text { spaces }\end{array}$ & $\begin{array}{l}\text { There is a strong interconnection between the activities developed by different individ- } \\
\text { uals and entities of the village. } \\
\text { There is a social reproduction of the village's values and of the traditional know-how } \\
\text { (albeit in a revised manner). }\end{array}$ \\
\hline Cluster innovation & $\begin{array}{l}\text { Chãos has a "cluster" of villagers who share the same cultural heritage and who are } \\
\text { seeking the creation of income-generating activities. } \\
\text { There is a proximity between individuals who collaborate rather than competition. }\end{array}$ \\
\hline $\begin{array}{l}\text { Regional innovation } \\
\text { systems }\end{array}$ & $\begin{array}{l}\text { The collective learning process is based on the idiosyncratic characteristics of the ter- } \\
\text { ritory where endogenous resources are critical for the competitive advantage of the } \\
\text { village. } \\
\text { The dissemination of knowledge is fostered by the collective desire of economic value } \\
\text { creation and supported by the local culture of cooperation and reciprocity. }\end{array}$ \\
\hline Learning regions & $\begin{array}{l}\text { There is a social fabric/structure that is able to ensure the intergenerational dissemina- } \\
\text { tion of knowledge (especially related to the local economic activities and specificities). } \\
\text { The village also had the ability to renew the traditional knowledge; the cooperation } \\
\text { and team orientation of its inhabitants are important for the learning process. }\end{array}$ \\
\hline
\end{tabular}

SOURCE: Authors` own elaboration 
The analysis of the case also shows the relevance of considering the local resources of a rural territory, specifically the tangible (e.g., soil) and intangible (e.g., know-how) assets, as well as its role in sustaining the competitive advantages of the Cooperative. Also the case shows how territory offers an opportunity for social innovation, where local agents modify their behavior in accordance with the changes of the environment. In fact, individuals' alertness, experience and prior knowledge make it possible to take advantage of a set of circumstances provided by the external environment.

This case illustrates the importance of including the economic dimension in the mission of the social venture. To attain this objective, the Cooperative adopts a proactive culture to search for new and innovative sources of revenue generation that depend on its portfolio of products, services and activities related to its regional specificities. The aim is to be economically and financially sustainable in the long term.

\section{7.- Conclusion}

The main goal of this paper was to contribute to the identification of some of the social innovative responses that could emerge from the exploitation of the local capabilities of a territory. We observe that territories are a place for innovation, and their characteristics are able to foster the inhabitants' social innovation. New social ventures arise in response to severe social issues that remain unanswered in local communities. The intention to act arises from the awareness that such complex and multidisciplinary social issues will not be eliminated through social institutionalized national responses, either because they do not exist or because they do not address the specific characteristics of local communities and territories.

We observe that individuals who are exposed to social problems are usually drivers in the creation of new social ventures. The contribution of the Cooperative Terra Chã to attenuate the local unemployment problem was to develop new business models based on ethnic products sold outside the village, helping to create direct and indirect employment in a small rural village and thus preventing the exit of young local people to the main coastal cities of Portugal.

Although each social venture focuses on a range of social issues, its social consequences are actually broader than this range, as it may have an impact in other social areas not explicitly recognized in its mission statement, such as social exclusion, civic cohesion, civil rights, promotion of human dignity and poverty. In the case of the Cooperative Terra Chã, the innovative response occurs from different activities: the combination of existing local (natural) resources in an innovative way to protect the environment and increase tourism; the identification of new sources of revenue; and the partner- 
ships with other institutions (public or private) that share common cultural and social values. As Okpara and Halkias (2011) suggest, the desire to innovate is not the result of one instance of creativity but is the modus operandi of social entrepreneurs.

A particular characteristic of the Terra Chã case is that its managers have a deep knowledge of the existent social problems in the community. This awareness allows them to adopt an integrated and holistic approach to the problems faced by the citizens. The actions taken try to maximize the resources available in order to obtain synergies and expand the process of social value creation.

As stated by Witkamp, Royakkers and Raven (2011), the inclusion in the community of the social organization, the experience of the social issues and the strong involvement of the main stakeholders lead to the adoption of a response model that accommodates the characteristics of the target population and of the rural territory where they live. Most of the solutions mentioned above are not radical social innovations but rather derive from the knowledge of the reality of the situation and the combination of pre-existing elements (i.e., incremental innovation).

As we can see in the Terra Chã case, understanding social problems allows for the design of holistic responses that explore, in an integrated manner, the resources and capabilities of the group or region to be served. The creation of the Cooperative is in line with the specificities of the region and is based on three cornerstones: (i) the social dimension; (ii) the economic dimension; and (iii) the cultural and/or environmental dimension. A virtuous combination of these three bottom lines, which reinforce each other, is possible due to the deep local knowledge and the powerful motivation of their respective players to find a satisfactory and lasting solution for local development. The case study illustrates how social entrepreneurs' innovation capabilities could facilitate the transformation of a social problem (triggered by the characteristics of the territory) into an opportunity to create social and economic value in a sustainable way.

\section{ACKNOWLEDGEMENTS}

This research was carried out within the funding with COMPETE reference $n^{\circ} \mathrm{POCl}-01-0145$ FEDER-006683, with the FCT/MEC's (Fundação para a Ciência e a Tecnologia, I.P.) financial support through national funding and by the ERDF through the Operational Programme on "Competitiveness and Internationalization - COMPETE 2020 under the PT2020 Partnership Agreement. Theoretical back-

ground of the article has been based on earlier versions of papers and articles included in the research project "Social innovation, territorial innovation models and local development". 


\section{References}

AYDALOT, PH. (ed.) (1986): Milieux innovateurs en Europe, GREMI, Paris.

BECATTINI, G. (1990): "The Marshallian industrial district as a socio-economic concept". In: F. Pyke, G. Becattini and W. Sengenberger (eds.), Industrial Districts and Inter-firm Co-operation in Italy, Geneva, ILLS, 37-51.

BECATTINI, G. (2015): "Beyond geo-sectorality: the productive chorality of places", Investigaciones Regionales - Journal of Regional Research, 32, 31-41.

BELLANDI, M. \& PROPIS, L.D. (2015): "Three generations of industrial districts", Investigaciones Regionales - Journal of Regional Research, 32, 75-87.

BENKO, G. \& LIPIETZ, A. (Eds.) (1992): Les régions qui gagnent. Districts et réseaux: les nouveaux paradigmes de la géographie économique, PUF, Paris.

BOUCHARD, M.J. (2011): "Social innovation, an analytical grid for understanding the social economy: the example of the Québec housing sector", Service Business, 6(1), 47-59.

BRACZYK, H.J., COOKE, P. \& HEIDENREICH, M. (Eds.) (1998): Regional Innovation Systems: The Role of Governance in a Globalized World, UCL Press, London.

BRYMAN, A (2001): Social Research Methods, Oxford University Press, Oxford.

CAMAGNI, R. (1991): "Local milieu, uncertainty and innovation networks: towards a dynamic theory of economic space". In: R. Camagni (ed.), Innovation networks: spatial perspectives, BelhavenPinter, London, 121-144.

CAMAGNI, R. \& MAILLAT, D. (Ed.) (2006): Millieux innovateurs: théorie et politiques, EconomicaAnthropos, Paris.

CANTILLON, B., CHZHEN, Y., HANDA, S. \& NOLAN, B. (2017). Children of Austerity: Impact of the Great Recession on Child Poverty in Rich Contries. Oxford, Oxford Univesity Press.

CHATTERJI, A., GLAESER, E. \& KERR, W. (2013): "Clusters of entrepreneurship and innovation", NBER Working Paper, 19013.

CHOI, N. \& MAJUMDAR, S. (2015): "Social innovation: towards a conceptualisation". In: Majumdar, S., Guha, S. \& Marakkath, N. (Eds.), Technology and Innovation for Social Change, Springer, India, 7-34.

CLARENCE, A. (2014): "Good governance for scaling social innovations". In: Sgaragli, F. (Eds.), Enabling social innovation ecosystems for community-led territorial development, The Quaderni della Fondazione Giacomo Brodolini, Studi e Ricercha, 49. 
COOKE, P. \& K. MORGAN (1994): "The regional innovation system in Baden-Württemberg", International Journal of Technology Management, 9, 394-429.

COSSETA, A., \& PALUMBO, M. (2014): "The co-production of social innovation: The case of living lab". In: R.P. Dameri \& C.Rosenthal-Sabroux (Eds.), Smart city: how to create public and economic value with high technology in urban space, London: Springer, 221-235.

COURLET, C. (2008): L'économie territoriale, PUG, Grenoble.

COURLET, C. \& PECQUEUR, B. (1992): "Les systèmes industriels localisés en France: un nouveau modèle de développement". In: G. Benko \& A. Lipietz (eds), Les régions qui gagnent - Districts et réseaux: les nouveaux paradigmes de la géographie économique, Paris, PUF, 81-102.

DIEZ, J.D. (2002): "Metropolitan innovation systems: a comparison between Barcelona, Stockholm, and Vienna", International Regional Science Review, 25(1), 63-85.

DOLOREUX, D. (2002): "What we should know about regional systems of innovation?", Technology in Society: An International Journal, 24, 243-263.

DOLOREUX, D. (2003): "Regional innovation systems in the periphery: The case of the Beauce in Québec (Canada)", International Journal of Innovation Management, 7(1), 67-94.

DOZ, Y. (2011): "Qualitative research for international business", Journal of International Business Studies, 42(5), 582-590.

DYCK, B.V. \& BROECK, P.V. (2013): "Social innovation: a territorial process". In: F. Moulaert, D. MacCallum, A. Mehmodd, \& A. Hamdouch (Eds), The International Handbook on Social Innovation: Collective Action, Social Learning and Transdisciplinary Research, Cheltenham: Edward Elgar, 131-142.

DYER, W.G. \& WILKINS, A.L. (1991): "Better stories, not better constructs, to generate better theory: a rejoinder to Eisenhardt", Academy of Management Review, 16(3), 613-619.

EDWARDS-SCHACHTER, M.E., MATTI, C.E. \& ALCÂNTARA, E. (2012): "Fostering quality of life through social innovation: a living Lab methodology study case: social innovation and living Labs", Review of Policy Research, 29(6), 672-692.

EISENHARDT, K.M. (1989): "Building theories from case study research", Academy of Management Review, 14(4), 532-550.

ENRIGHT, M.J. \& ROBERTS, B.H. (2001): "Regional clustering in Australia", Australian Journal of Management, 26, 65-85.

ESSERS, C., DEY, P., TEDMANSON, D. \& VERDUYN, K. (2017): Critical Perspectives on Entrepreneurship: Challenging Dominant Discourses, New York, Routldge. 
EUROPEAN COMMUNITIES (2008): "The concept of clusters and cluster policies and their role for competitiveness and innovation: main statistical results and lessons learned", Commision Staff Working Document, SEC (2008), 2637, Annex to the Communication from the Commission "Towards world-class clusters in the European Union: Implementing the broad-based innovation strategy" COM(2008)652 final of 17.10.2008, Europe INNOVA / PRO INNO Europe paper $N^{\circ} 9$, Luxembourg: Office for Official Publications of the European Communities.

EUROPEAN COMMUNITIES (2011): Empowering people, driving change: social innovation in the European Union, Publications Office of the European Union, Luxembourg.

EUROPEAN UNION (2014): Local productions systems in and outside the EU: from theory to practice. Project "Functioning of the Local Production Systems in the Conditions of Economic Crisis (Comparative Analysis and Benchmarking for the EU and Beyond)", retrieved from http://www.region.uni.lodz.pl/wgrane_pliki/local-production-systems-in-countries-in-and-outsidethe-eu_2015.pdf.

FAGUNDES, S.C.N. (2014): O empreendedorismo social como promotor da integração socioprofissional: um estudo exploratório, Masters' thesis, Instituto Politécnico do Porto- Instituto Superior de Contabilidade e Administração do Porto, Portugal.

FERRETI, M. \& PARMENTOLA, A. (2015): The creation of local innovation systems in emerging countries: the role of governments, firms and universities, Springer, Heidelberg.

FESER, E. (2002): "The Relevance of Clusters for Innovation Policy in Latin America and the Caribbean", Background paper prepared for the World Bank, LAC Group.

FLORIDA, R. (1995): "Toward the learning region", Futures, 27(5), 527-536.

FRANZ, H., HOCHGERNER, J. \& HOWALDT, J. (2012): "Challenge Social Innovation: An introduction", In: H. Franz, J. Hochgerner, \& J. Howaldt (Eds.), Challenge Social Innovation: Potential For Business, Social Entrepreneurship, Welfare and Civil Society, London: Springer, 1-16.

GATHFIELD, T. \& YANG, C. (2006): "New industrial space theory - a case study and empirical analysis of factors effecting newly emerging key industries in Queensland", Australasian Journal of Regional Studies, 12(1), 47-61.

GHAURI, P., GRONHAUGH, K. \& KRISTIANSLUND, I. (1995): Research methods in business studies, Prentice Hall, London.

GUIDA, F. \& MAIOLINI, R. (2014): "Introduction: social innovation, actors, contexts and trends. Open the black box". In: F. Sgaragli (Ed.), Enabling social innovation ecosystems for community-led territorial development, The Quaderni della Fondazione Giacomo Brodolini, Studi e Ricercha, 49.

GUSTAFSSON, J. (2017): "Single case studies vs. multiple case studies: A comparative study", Dissertation, Retrieved from http://urn.kb.se/resolve?urn=urn:nbn:se:hh:diva-33017 
HOOGENDOORN, B. \& HARTOG, C. (2011): "Prevalence and determinants of social entrepreneurship at the macro-level. Scales Research Reports H201022", EIM Business and Policy Research. Retrieved November 25, 2015, from http://www.entrepreneurship-sme.eu/pdf-ez/H201022.pdf.

ISAKSEN, A. (1994): "New industrial spaces and industrial districts in Norway: productive concepts in explaining regional development?", European Urban and Regional Studies, 1(1), 31-48.

JONSSON, A. \& FOSS, N. J. (2011), "International expansion through flexible replication: learning from the internationalization experience of IKEA", Journal of International Business Studies, 42(9), 10701102.

KLEIN, J. (2013): "Introduction: social innovation at the crossroads between science, economy \& society". In: F. Moulaert, D. MacCallum, A. Mehmodd, \&A. Hamdouch (Eds), The International Handbook on Social Innovation: Collective Action, Social Learning and Transdisciplinary Research, Cheltenham: Edward Elgar, 9-13.

KLEIN, J. L.; FONTAN. J. M.; HARRISSON, D. \& LEVESQUE, B. (2012): "The Quebec system of social innovation: a focused analysis on the local development field", Finisterra, XLVII (94), 9-28.

LEONCINI, R. \& MONTRESOR, S. (Eds.) (2008): Dynamic capabilities between firm organization and local systems of production. Routledge, London.

MAILLAT, D. \& PERRIN, J. (1992): Entreprises innovatrices et développement territorial, GREMI, Neuchâtel.

MAURER, A.M. \& SILVA, T.N. (2014): "Analytical dimensions for identifying social innovations: evidence from collective enterprises", Brazilian Business Review, 11(6), 123-145.

MORGAN, K. (1997): "The learning region: institutions, innovation and regional renewal", Regional Studies, 31(5), 491-503.

MOULAERT, F. \& SEKIA, F. (2003): "Territorial innovation models: a critical survey", Regional Studies, 37(3), 289-302.

MOULAERT, F., MACCALLUM, D. \& HILLER, J. (2013): "Social Innovation: Intuition, percept, concept, theory and practice". In: F. Moulaert, D. MacCallum, A. Mehmodd \& A. Hamdouch (Eds), The International Handbook on Social Innovation: Collective Action, Social Learning and Transdisciplinary Research, Cheltenham: Edward Elgar, 13-24.

MULGAN, G. (2012): "Social Innovation Theories: Can Theory Catch Up with Practice?". In: H. Franz, J. Hochgerner \& J. Howaldt (Eds), Challenge Social Innovation: Potential For Business, Social Entrepreneurship, Welfare and Civil Society, London: Springer, 19-42.

MURRAY, R., CAULIER-GRICE, J. \& MULGAN, G. (2010): "The open book of social innovation", Social Innovator Series: Ways to Design, Develop and Grow Social Innovation, The Young Foundation/NESTA (the National Endowment for Science, Technology and the Arts). https://www.nesta.org.uk/sites/default/files/the_open_book_of_social_innovation.pdf, Retrieved 16/10/2015. 
NEUMEIERS, S. (2017): "Social innovation in rural development: Identifying the key factors of success", The Geographical Journal, 183 (1), 34-46.

NOVY, A. \& LEUBOLT, B. (2005): "Participatory budgeting in Porto Alegre: social innovation and the dialetical relationship of state and civil society", Urban Studies, 42(11), 2023-2036.

OECD (2010): "Social entrepreneurship and social innovation". In: SMEs, entrepreneurship and innovation, OECD, Paris, 185-215.

OECD (2014): OECD Science, Technology and Industry Outlook 2014, OECD Publishing, Paris.

OKPARA, J. \& HALKIAS, D. (2011): "Social entrepreneurship: An overview of its theoretical evolution and proposed research model", International Journal of Social Entrepreneurship and Innovation, 1(4), 4-20.

PHILLS JR, L.A., DEIGLMEIER, K. \& MILLER, D.T. (2008): "Rediscovering social innovation”, Stanford Social Innovation Review, Fall, 33-43.

PYKE, F., BECATTINI, G. \& SENGENBERGER, W. (Eds.) (1990): The re-emergence of small enterprises: industrial restructuring in industrialized countries, ILLS, Geneva.

PYKE, F. \& SENGENBERGER, W. (Eds.) (1992): Industrial Districts and local economic regeneration, ILLS, Geneva.

PORTER, M.E. (1998): "Clusters and the new economics of competition", Harvard Business Review, 76, 77-90.

PORTER, M.E. (2001): "Innovation: location matters", MIT Sloan Management Review, 42(4), 28-36.

POTTER, J. \& MIRANDA, G. (2009): Clusters, innovation and entrepreneurship, OECD, Paris.

SANTOS, D. \& SIMÕES, M.J. (2014): "Regional innovation systems in Portugal: a critical evaluation", Investigaciones Regionales, 28, 37-56.

SCOTT, A.J. (1988): "Flexible production systems and regional development: the rise of new industrial spaces in North America and western Europe", International Journal of Urban and Regional Research, 12(2), 171-186.

SCOTT, A.J. (2014): "Beyond the creative city: cognitive-cultural capitalism and the new urbanism", Regional Studies, 48(4), 565-578.

SENGENBERGER, W., LOVEMAN, G.W. \& PIORE, M.J. (eds.) (1990): Industrial Districts and Interfirm Co-operation in Italy, ILLS, Geneva.

SFORZI, F. (2015): "Rethinking the industrial district: 35 years later", Investigaciones Regionales Journal of Regional Research, 32, 11-29.

SFORZI, F. \& BOIX, R. (2015): "What about industrial district(s) in regional science?", Investigaciones Regionales - Journal of Regional Research, 32, 61-73. 
STORPER, M. (2007): "Regional 'worlds'of production: learning and innovation in the technology districts of France, Italy and the USA", In: Rutten, R. \& Boekema, F. (2007): The learning region: foundations, state of the art, future, Edward Elgar, Cheltenham, 15-57.

TARDIF, C. \& HARRISON, D. (2005): "Complémentarité, convergence et transversalité: la conceptualisation de l'innovation sociale au CRISES". In: CRISES. Centre de Recherche Sur Les Innovations Sociales. Cahiers du CRISES. Québec.

WITKAMP, M., ROYAKKERS, L. \& RAVEN, R. (2011), "From cowboys to diplomats: Challenges for social entrepreneurship in the Netherlands", Voluntas, 22(2), 283-310.

YIN, R.K. (2013): Case Study Research: Design and Methods, Fifth Edition, Sage, London. 
